\title{
Theophany and Asceticism in John Scottus Eriugena
}

\author{
Mihai Grigoraș
}

Theophany is a central concept in Eriugena's spirituality and it has been comprehensively treated so far from a theoretical point of view. The present study aims at investigating John Scottus's 'practical', i.e. ascetical, perspective. My hypothesis is that for Eriugena contemplation is always dependent on practice, to such an extent that his theophanic mysticism should be considered together with his asceticism. Given that John Scottus's asceticism is not always systematically displayed, I assembled a number of ascetical aspects of his practical spirituality and organized them into two categories: (1) negative aspects of asceticism: repentance, purgation, mortification, and (2) positive aspects of asceticism: virtues, grace, and sacraments. All these ascetical aspects are presented in close connection to Eriugena's ultimate spiritual purpose, which is attaining God in the highest theophanies.

Key-words: Eriugena, theophany, asceticism, mysticism, purgation, virtues, grace, sacraments

\section{Introduction}

Theophany, i.e. divine self-disclosure and its human perception (from Gk. $\theta \varepsilon о \varphi$ áveı meaning both "divine manifestation" and "vision of God" $)$, is a central concept in Christian mysticism. Its roots are to be found in the Old Testament, where the narrative of the salvation of the chosen people is spanned from one end to the other by Yahweh's multiple self-revealing actions ${ }^{2}$. For Christians, however, the most manifest and culminating theophany is to be found in the New Testament, precisely in the person of Jesus Christ, the incarnate God (Jn 1.14; 1 Pet. 1.20) Who is the purpose and fulfilment of all the ancient theophanies (Hebr. 1.1-2). After Christ's ascension, the first generations of Christians strived to actualize in a mysti-

\footnotetext{
* Mihai Grigoraș, PhD Student, University of Bucharest, Odei 16, B2, Ap. 22, sector 4, București, 041046 mihaigregoras@gmail.com.

${ }^{1}$ A Greek-English Lexicon, compiled by Henry George Liddell and Robert Scott, revised by Henry Stuart Jones and Roderick McKenzie (Oxford: Clarendon Press, 1968), 792; A Patristic Greek Lexicon, edited by G.W.H. Lampe (Oxford: Clarendon Press, 1961), 641.

${ }^{2}$ René Latourelle, Theology of Revelation (New York: Alba House, 1966), 21-40; George W. Savran, Encountering the Divine: Theophany in Biblical Narrative (London-New York: T \& T Clark, 2005), 14-25.
} 
cal manner Jesus's historical presence among His contemporaries and thus stressed the significance of an intimate theophany (Jn 14.23; Gal. 2.20) for their spiritual life. Since then, the perceiving of this theophanic presence has been the goal of Christian mystics of all times, although the concept of theophany itself entered into Christian spiritual terminology only later on ${ }^{3}$.

\section{"Theophany" in Eriugena}

John Scottus Eriugena (c. 815-877) ${ }^{4}$ came upon theophany (lat. theophania) as a mystical term ${ }^{5}$ when translating the Areopagitic Corpus. In Ps.Dionysius the Areopagite, $\theta \varepsilon$ co $a$ 'vela was a term among others to express generally the process of divine revelation ${ }^{6}$. In contrast to his Greek source, Eriugena appropriated theophania as a crucial theological concept and exploited its doctrinal potential even better than the Areopagite. While the Greek author used the term only a couple of times ${ }^{7}$ without endowing it with any pre-eminence in his system, Eriugena employed his theophania much

\footnotetext{
${ }^{3}$ The term $\theta \operatorname{co} \varphi a ́ v(\varepsilon) \iota a$ (including its derivatives) has no occurrence in the Bible. It is firstly attested in the third century in the works of Origen (PG 17, 361A) and Metodius of Olymp (PG 18, 352C), meaning Christ's Incarnation. From then on, it has been successively used by Eusebius of Caesarea, the Cappadocian Fathers, Ps.-Dionysius the Areopagite.

${ }^{4}$ For an introduction to his life, thought and works, see: Maïeul Cappuyns, Jean Scot Érigène, sa vie, son oeuvre, sa pensee (Bruxelles: Culture et Civilisation, 1964), 3-232; Deirdre Carabine, John Scottus Eriugena (Oxford: Oxford University Press, 2000), 5-26; Hilary Anne-Marie Mooney, Theophany: The Appearing of God According to the Writings of Johannes Scottus Eriugena (Tübingen: Mohr Siebeck, 2009), 25-42.

${ }^{5}$ Until Eriugena, theophania is attested in Christian Latin only as a liturgical term designating the Feast of Epiphany, Albert Blaise, Dictionnaire latin-français des auteurs chrétiens (Turnhout: Brepols, 1954), s.v. Except for Julian of Toledo (642-690, in his Commentarius in Nahum, 29, PL 96, 721B), we have no evidence that any of the Latin Fathers and theologians exploited theophania as a mystical term; instead, they used many expressions, especially verbs, to indicate the theophanic process: revelare, apparêre, manifestare, vidère, contemplare, which proves that, for a long time, there was no need of a conceptual abstraction in Western Christianity. See: a similar case in Syriac, where no specific term designates the idea of deification; Serafim Seppälä, "The Concept of Deification in Greek and Syriac," Review of Ecumenical Studies 11, no. 3 (December 2019): 454.

6 "Although theophany is implied by the theory of symbols and is the raison d'etre of the hierarchies, Pseudo-Dionysius does not often use the word, and never, I think, in a technical sense", Inglis Patrick Sheldon-Williams, "Greek Sources," in The Mind of Eriugena, eds. J.J. O’Meara, L. Bieler (Dublin: Irish University Press, 1973), 10.

7 Twelve occurrences, in PG 3, 180C (three times), 205B, 440B, 483B, 513C, 589A, 592C, 596A, 932B, 1084B and in Corpus Dionysiacum, 1: Pseudo-Dionysius Areopagita. De Divinis Nominibus, ed. Beate Regina Suchla (Berlin-New York: Walter de Gruyter, 1990), 110, 114, 118; Corpus Dionysiacum, 2: Pseudo-Dionysius Areopagita, De Coelesti Hierarchia, De Ecclesiastica Hierarchia, De Mystica Theologia, Epistulae, eds. Günter Heil and Adolf M. Ritter (Berlin-Boston: Walter de Gruyter, 2012), 22, 27, 90, 103, 113, 171.
} 
more often ${ }^{8}$ and placed it at the heart of his theology ${ }^{9}$. Actually, in Eriugena the most important Christian tenets are interpreted in the final analysis as aspects of theophany. Thus: (a) creation out of nothing is explained in terms of theophany: "when it [i.e. Divine Goodness] begins to appear in its theophanies it is said to proceed [...] out of nothing into something" ${ }^{10}$; (b) biblical and post-biblical divine revelations are naturally treated as theophanies ${ }^{11}$; (c) Christ's Incarnation too is designated as a "wonderful theophany"12; (d) the moral virtues attained by the believer in his endeavor to imitate Jesus's life are dealt with as theophanies ${ }^{13}$; (e) deification, the last stage of the believer's spiritual ascent toward God, is also considered a theophany ${ }^{14}$.

As a central theme in the writings of John Scottus, theophany has received significant attention from scholars of recent decades ${ }^{15}$. The majority

\footnotetext{
${ }^{8}$ There are 85 occurrences in the entire Eriugenian oeuvre: 49 occurrences in Periphyseon, Guy-H. Allard, Johannis Scoti Eriugenae Periphyseon Indices générales (Montreal-Paris: Institut d'Études Médiévales-Librarie Philosophique J. Vrin, 1983), 553-54; 32 occurrences in Expositiones in Ierarchiam coelestem, Iohannis Scoti Eriugenae Expositiones in Ierarchiam coelestem, ed. Jeanne Barbet, Corpus Christianorum Continuatio Mediaevalis (hereafter CCCM) 31 (Turnhout: Brepols, 1975), 320; 4 occurrences in Commentarius in euangelium Iohannis, Jean Scot, Homélie sur le Prologue de Jean, ed. Édouard Jeauneau (Paris: Éditions
} du Cerf, 1969), 463.

9 "En réalité, la théophanie, apparition de l'Invisible en sa creature divinisée, est le fond même du système érigénien", Hyacinth-François Dondaine, "L'objet et le «medium» de la vision béatifique chez les théologiens du XIIIe siècle," Recherches de théologie ancienne et médiévale 19 (Janvier-Juin 1952): 65. Theophany is located at the intersection with other key ideas in the Eriugenian system: nature (natura), primordial causes (causae primordiales), participation (participatio), and hierarchy (ierarchia).

10 "Dum [...] in suis theophaniis incipiens apparere ueluti ex nihilo in aliquid dicitur procedere", Periphyseon - hereafter PP III 681A, in Iohannis Scotti Eriugenae, Periphyseon (De Diuisione Naturae), Liber Tertius, ed. Inglis Patrick Sheldon-Williams, with the collaboration of Ludwig Bieler, Scriptores Latini Hiberniae (hereafter SLH) 11 (Dublin: The Dublin Institute for Advanced Studies, 1981), 166-67.

11 "Qui modus a Grecis theophania, hoc est dei apparitio, solet appelari. Cuius exemplum: "Vidi dominum sedentem»" (PP I 446D, in Iohannis Scotti Eriugenae, Periphyseon (De Diuisione Naturae). Liber Primus, ed. Sheldon-Williams, with the collaboration of Ludwig Bieler, SLH 7 (Dublin: The Dublin Institute for Advanced Studies, 1968), 46.

12 "descendens mirabili quadam theophania", PP V 912D Iohannis Scotti seu Eriugenae, Periphyseon. Liber Quintus, ed. Eduardus A. Jeauneau, CCCM 165 (Turnhout: Brepols, 2003), 75 .

13 "omnis theophania, id est omnis uirtus", PP I 449C, SLH 7, 54.

14 "per deificationem [...] fit theophania", PP I 449B, SLH 7, 52.

15 Joaquin Maria Alonso, Teofania y vision beata en Escoto Erigena (Roma: Pontificia Universitas Gregoriana, 1952); Tullio Gregory, "Note sulla dottrina delle "teofanie» in Giovanni Scoto Eriugena,” Studi Medievali 3a Serie, 4, 1 (1963): 75-91; René Roques, "Théophanie et nature chez Jean Scot Érigène," in École pratique des hautes études. Section 
of these studies treated the subject extensively from a philosophical point of view, as well as from the perspective of speculative theology. Our aim is to approach the Eriugenian understanding of theophany from the point of view of Christian spirituality ${ }^{16}$. To my mind, Eriugena conducts his theological discourse with the ultimate goal of leading the reader toward a mystical union with God, a union understood as an interpersonal dialogue and theophanic vision:

O God, our salvation and redemption, [...] show Thyself to those who seek for nothing but Thee; shatter the clouds of empty phantasies which prevent the glance of the mind from beholding Thee in the way in which Thou grantest Thine invisible self to be seen by those who desire to look upon Thy face. ${ }^{17}$

\section{Eriugena mysticus? ${ }^{38}$}

Before dealing with the Eriugenian theophanic asceticism, I would like to briefly consider two charges against the validity of Eriugena's mystical theory in general: (a) the absence of evidence of a personal experience of $\mathrm{God}^{19}$; (b)

des sciences religieuses. Annuaire 1965-1966 (Paris: EPHE, 1965), 156-67; Branko Bosnjak, „Dialektik der Theophanie. Über den Begriff der Natur bei J.S. Eriugena,” in La Filosofia della Natura nel Medioevo (Milano: Vita e pensiero, 1966), 264-71; Jean Trouillard, "Érigène et la théophanie créatrice," in The Mind of Eriugena: papers of a colloquium, Dublin, 14-18 July 1970, eds. John O’Meara and Ludwig Bieler (Dublin: Irish University Press, 1973), 98-113; Jean-Claude Foussard, "Non apparentis apparitio: le théophanisme de Jean Scot Érigène," in Face de Dieu et théophanies, Cahiers de l'Université Saint-Jean de Jérusalem 12 (Paris: Berg international, 1986), 120-48; Emmanuel Falque, "Jean Scot Érigène: la théophanie comme mode de la phénoménalité," Revue des sciences philosophiques et théologiques 86 (2002): $387-421$.

${ }^{16}$ Eriugena is generally seen as a mystic writer in some important studies: Hermann Dörries, Geschichte der Mystik Erigena und der Neuplatonismus (Tübingen: Mohr Siebeck, 1925); Alois M. Haas, "Eriugena und die Mystik," in Eriugena Redivivus. Zur Wirkungsgeschichte seines Denkens im Mittelalter und im Übergang zur Neuzeit, ed. Werner Beierwaltes (Heidelberg: Carl Winter, 1987), 254-78; Bernard McGinn, "Eriugena Mysticus," in Giovanni Scoto Nel Suo Tempo: L'Organizzazione del Sapere in Età Carolingia (Todi: Centro italiano di studi sull'alto Medioevo, 1989), 235-60.

17 "Deus nostra salus atque redemption [...] ostende te ipsum his qui nil petunt praeter te. Rumpe nubes uanarum fantasiarum quae mentis aciem non sinunt intueri tee o modo quo te inuisibilem uideri permittis desiderantibus uidere faciem tuam", PP III 650B, SLH 11, 98-99.

${ }_{18}$ The name of this heading is inspired by the title of McGinn's study mentioned above.

19 "After all, Eriugena tells us nothing at all about his own inner life [...], there are no references to personal experiences of rapture or union", McGinn, "Eriugena," 236. This kind of claim, which McGinn actually rejects in his study, derives from an artificial distinction between (i) "true and first-hand" mystics, and (ii) mystical theologians who only investigate the experiences of the former, without experiencing the spiritual reality themselves, Evelyn 
the failure to develop an ascetical program ${ }^{20}$. In my opinion, both charges reveal a slightly biased reception of Eriugena's thought, oftentimes limited only to Periphyseon ${ }^{21}$ and based on an excessively intellectualized interpretation. In fact, if we consider the entire Eriugenian euvre in the complexity of all its genres (doctrinal treatise, biblical and patristic commentary, homily, and poems), we soon find enough testimonies of both a personal experience of the divine, and a definite, although not always systematically displayed, spiritual program.

In response to the first charge claiming the lack of evidence of Eriugena's personal experience of God and of a spiritual preoccupation with inner life, one could bring forward multiple fragments from Carmina ${ }^{22}$, and some other passages, even from Periphyseon ${ }^{23}$, containing impressive prayers addressed to Christ or the Virgin Mary, as well as personal confessions, regarding previous errors sincerely regretted by the author ${ }^{24}$. In addition to this, in his Homily, John Scottus describes magnificent ecstatic experiences which he at least aspired to, even if he himself had not really experienced them:

The spiritual bird, fast-flying, God-seeing - I mean John, the theologian - ascends beyond all visible and invisible intellect and, deified, enters into God who deifies him. "O Blessed Paul, you were caught up, as you yourself assert, into the third heaven, to paradise [...]". John, however, went beyond every created heaven and paradise, beyond every human and angelic nature ${ }^{25}$.

Underhill, Mysticism: A Study in the Nature and Development of Spiritual Consciousness (New York: E.P. Dutton and Company, 1912), 95, 114.

20 "The social, sacramental, and ethical dimensions of man's redemption are minimal. John scarcely mentions the Church, the sacraments and the Christian moral life...", Marcia Colish, "John the Scot's Christology and Soteriology in Relation to His Greek Sources," The Downside Review 100 (1982): 138; "Eriugena folgt nicht der Tradition des "griechischen" Personalismus und Existentialismus", Georgi Kapriev, "Eodem sensu utentes. Die Energielehre der "Griechen» und die causae primordiales Eriugenas," Theologische Quartalschrift 180 (2000): 307.

${ }^{21}$ Cappuyns noticed that Periphyseon is a part of a triptych who's other two elements are Expositiones and respectively Commentarius and Homilia, Cappuyns, Jean Scot, 182. Mooney judiciously warned against the tendency to overrate Periphyseon to the detriment of Eriugena's other writings, which runs the risk of distorting Eriugena's thinking in its entire complexity, Mooney, Theophany, 210, n. 87.

${ }^{22}$ Carmen 1 (hereafter Carm), vv. 43-50 (1223A; Iohannis Scotti Eriugenae, Carmina, ed. Michael W. Herren, SLH 12 (Dublin: School of Celtic Studies, Dublin Institute for Advanced Studies, 1993), 60); Carm 2, vv. 7-30 (1224AC; SLH 12, 64); Carm 8, vv. 63-86 (1232BC; SLH 12, 88); Carm 25, vv. 54-60, 82-85 (SLH 12, 118, 120).

${ }^{23}$ PP III 650B (SLH 11, 98), PP V 1010B-1011A (CCCM 165, 210).

${ }^{24}$ PP III 649D-650A (SLH 11, 96-98).

${ }^{25}$ Homilia super "In principio erat uerbum" - hereafter Hom - 4 285BC, in Christopher Bamford's translation, slightly changed, The Voice of the Eagle. The heart of Celtic Christianity. 
Yet in the third person ${ }^{26}$, this kind of illustration belongs to someone who is highly interested in God's contemplation ${ }^{27}$ and who most probably would have personally tried the experience of an intimate encounter with God.

In response to the second charge, there are plenty of passages in the works of Eriugena that describe aspects of the believer's spiritual ascent ${ }^{28}$, some of which we intend to discuss in the next chapter. For the moment, we only quote the following fragment:

Who likes to laud the form of beautiful wisdom [...]

let him desert and deny the world of the senses [...].

Let him read these works who is free from carnal cares,

the waning world, and the fragile delights of this life.

But let not the dullard and sluggard and lover of worldly ways

come hither; [...]

Here shines Praktike, brilliant teacher of ethics,

a fitting and watchful ward of the virtues. ${ }^{29}$

John Scotus Eriugena's Homily on the Prologue to the Gospel of St. John, trans. Christopher Bamford (Hudson, NY: Lindisfarne Books, 2000), 75 of: "Spirituale igitur petasum, citiuolum, deiuidum (Iohannem dico theologum) omnem uisibilem et inuisibilem creaturam superat, omnem intellectum tranat, et deificatus in deum intrat se deificantem. O beate Paule, raptus es, ut tu ipse asseris, in tertium caelum, sed non es raptus ultra omne caelum [...]. Iohannes omne caelum conditum omnemque creatum paradisum, hoc est omnem humanam angelicamque transgreditur naturam", Iohannis Scotti seu Eriugenae, Homilia super "In principio erat uerbum" et Commentarius in euangelium Iohannis, ed. Édouard A. Jeauneau, CCCM 166 (Turnhout: Brepols, 2008), 8-9.

${ }^{26}$ By using the third person in this kind of spiritual narration, Eriugena was probably aiming to respect an old tradition of the Fathers of the Church who were generally silent about their own mystical experiences or even hostile to any autobiographical accounts. We find this tradition no further than in Ps.-Dionysius the Areopagite, Eriugena's first Greek mentor, who attributed different visions and divine contemplations to a possibly fictional teacher Hierotheus, De Divinis Nominibus 2, 9.

27 The terms contemplatio and contemplare are attested over two hundred times only in PP.

${ }^{28}$ The first step of spiritual ascension is faith, PP I 516C, Hom $3285 \mathrm{~A}$, Commentarius in euangelium Iohannis - hereafter Comm - I, 28 305A; the next step: the observance of divine commandments, PP IV 812D and the eradication of vices, PP V926C, that is "active philosophy", PP III 705B, mortification, PP V 892A or "con-crucifixion" with Christ. Comm I, 32 311B-312B; the following stage: acquisition of virtues, Expositiones in Ierarchiam coelestem - hereafter Exp-I, 3 142C, PP IV 753 BC, which essentially are Christ's "conformations", PP I 448C in the soul of the believer; then comes the illumination, PP III 656D, equivalent to contemplation, Exp I, 1 129B; Carm 24, vv. 17-18 1236 BC; the last step: deification, the attainment of the perfect union with God, Exp III, 1 175A, PP V 1015AB.

${ }^{29}$ Carm 24, vv. 1, 3, 7-10, 15-16 1236 BC: "Quisquis amat formam pulchrae laudare sophiae [...] / Mundum sensibilem deserat atque neget [...]. / Deliciis fragilis vitae mundoque fugaci / Et carnis cura qui uacat, ista legat; / Mundanisque datus studiis, tardusque pigerque / Huc non accedat [...]. / Practica hic lucet morum praeclara magistra, / Custos uirtutum pervigil, idonea.", SLH 12, 114-15. 
In this single text Eriugena brings to light several major elements of a genuine asceticism: the abandonment of worldly things, the denial of carnal senses; the advancement in virtue, the desire for divine wisdom. Thus, it is with good reason that many scholars considered Eriugena not only an authentic mystic, "one of the major mystics of the Western Christian tradition" ${ }^{30}$, but also a relevant spiritual writer, whose ascetical and mystical program is valid even for people of today:

Eriugena's theology [...] encourages a kind of devotion and worship that is also intelligent and refined. Reading his passionate words about the Word become flesh, I, for one, am inspired to make a life around these ideas. ${ }^{31}$

Eriugena is $[. .$.$] one «standing in God's holy fire», who can teach$ us why theology matters and how we, too, can become mystic theologians and make the realities of the Christian life live in our hearts and lives. ${ }^{32}$

With this in mind, I attempt to present Eriugena's ascetical perspective on theophany as the basis for his theophanic mysticism. My hypothesis is that asceticism is a fundamental element in John Scottus's mysticism which cannot be eluded in the ascension of the mystic toward the highest theophanies. In fact, on the scale of spiritual ascent, the Irishman regularly sets forth "action" before "contemplation": "no one is allowed to enjoy His contemplation unless he is thoroughly purged by faith and action" 33 , "the soul is purged by action, illumined by knowledge, perfected by theology"34, "the heavenly action of the path of virtues leads to the contemplation of Truth" 35 , "the action of divine commandments [...] purges the inner eye of the soul that it may be able to perceive the rays of the Supreme Good spread in all things" ${ }^{\text {"36 }}$ etc. $^{37}$

\footnotetext{
${ }^{30}$ McGinn, "Eriugena," 239.

${ }^{31}$ Moore, "Foreword", The Voice, 14.

${ }^{32}$ Bamford, "The Celtic Church and the Mystery of Celtic Christianity" in The Voice, 19.

33 "cuius contemplatione nemo nisi purgatissimus fide et actione [...] frui sinitur", PP V 981A, CCCM 165, 169.

34 "Animae igitur purgatae per actionem, illuminatae per scientiam, perfectae per theologiam", PP II 574A, Iohannis Scotti Eriugenae, Periphyseon (De Diuisione Naturae), Liber Secundus, ed. I.P. Sheldon-Williams, with the collaboration of Ludwig Bieler, SLH 9 (Dublin: The Dublin Institute for Advanced Studies, 1972), 108.

35 "celeste actionem itineris uirtutum [...] sursum ducit in ueritatis contemplationem", Exp XV, 3 262A, CCCM 31, 200.

36 "actio diuinorum mandatorum [...] purgatur interior animi oculus [...], ut intimos summi boni radios in omnia diffusos ualeat sustinere", Exp III, 1 174D, CCCM 31, 56. My translation for the last four quotations.

${ }^{37}$ Other similar passages: "per actionem et scientiam rationalis anima crescit", Exp I, 2 136A, CCCM 31, 11; "ad perfectionem actionis et contemplationis perducta”, PP IV 853C,
} 


\section{The ascetical perspective on Theophany}

In Eriugena's system, "every visible and invisible creature can be called theophany" 38 , because "all that is understood and perceived is nothing but the appearance of the Concealed, the manifestation of the Hidden, the affirmation of the Negated" 39 . Stated differently, all invisible creatures (angels, spiritual realities) and visible ones (things, beings, events) are theophanic phenomena endowed with a profound symbolic character which is meant to orchestrate the final return of all things into God (cf. Rom. 11.36). In order to perceive the theophanic essence of all creation man has been provided by God with a natural intuitive ability ${ }^{40}$ to regard each created element in its essential transparency, namely as spiritual light ${ }^{41}$ and window to God.

However, since the Fall, this theophanic ability has been gradually damaged by the consequences of primordial sin, which introduced into creation not only the corruptibility and the fragility of the material world ${ }^{42}$, but also a degradation of man's spiritual powers. Therefore, without making any ascetical effort, theophany is rather impossible for the fallen man, given that pride, the origin of all sins $s^{43}$ - consisting in error of judgment ${ }^{44}$, self-delusion $^{45}$ and disobedience ${ }^{46}$ - has always invited the vicious man to perceive

Iohannis Scotti Eriugenae, Periphyseon (De Diuisione Naturae). Liber Quartus, ed. Edouard Jeauneau, with the assistance of Mark A. Zier, SLH 13 (Dublin: School of Celtic Studies, Dublin Institute for Advanced Studies, 1995), 258; "actione et scientia, ueluti in quibusdam nubibus clarissimis”, PP V 998D, CCCM 165, 193.

38 "omnis uisibilis et inuisibilis creatura theophania [...] potest appellari", PP III 681A, SLH $11,166-67$.

39 "Omne enim quod intelligitur et sentitur nihil aliud est nisi non apparentis apparitio, occulti manifestatio, negate affirmatio”, PP III 633A, SLH 11, 58-59. Sheldon-Williams's translation is slightly adapted.

40 "uirtus speculatiua", Comm I, 32 312C, CCCM 166, 73.

${ }^{41} \operatorname{Exp}$ I, 1 128C: "All things that are, are "lights»", "omnia quae sunt lumina sunt", CCCM 31, 3. My translation.

42 "Omne siquidem mortale quodcunque in hoc sensibili mundo esse uidetur et fragile et transitorium aut nos ipsi facimus nostris irrationabilibus motibus errantes aut propter delictum nostrum [...] fieri sinitur...", PP II 584A-B; "For everything mortal that is seen to be in this sensible world, being both fragile and transitory, is either made by ouerselves when we are led astray by our irrational motions or is permitted to be made on account of our sin...”, SLH 9, 130-33.

43 "superbia quae ueluti caput totius malitiae perhibetur", PP V916C, CCCM 165, 80.

44 "fallentem iudicationem", PP V919B, CCCM 165, 83, quoting Maximus, Quaestiones ad Thalassium, Introd., PG 90, 253B.

45 "malitia [...] in figura boni imaginata", PP IV 826D, SLH 13, 200.

46 "merito suae inobedientiae superbiaeque diversis calamitatibus involutae hospitium", PP II 571B, SLH 9, 102. 
the created world exclusively as an instrument for an arrogant and selfish delectation, leaving no room for any theophanic intuition ${ }^{47}$.

All these are illustrated by Eriugena in the following example ${ }^{48}$ : let there be two men in front of a precious vessel of pure gold. One of them is wise and virtuous, and the other is foolish and greedy. Both the wise man and the greedy one receive through the corporeal sense the image of the vessel, but while the greedy one blazes with the fire of cupidity, being poisoned and consumed by his irrational desire, the wise man feels no enticement of avidity toward the vessel, but purely contemplates its theophanic beauty and refers it entirely to the glory of God. What makes the difference between these two types of reaction is the moral state of the spectators. Whilst the greedy man "plunges and is swallowed up in the most stinking swamp of cupidity" at the sight of the vessel, for the wise man "no poison of greed infects the purpose of his mind" 49 ; on the contrary, he easily perceives the Word of God "quasi-incarnate" 50 in all the forms and orders of visible things, because of his immunity to any vicious temptations.

Therefore, the premise for all degrees of theophanic perception consists in the purity of mind, which in Eriugena is the result of nothing but a constant ascetical effort: "And whenever he [the believer] dies to the ways of his previous and lower life [...], so often [...] he is carried by faith and understanding towards higher theophanies" $\$$.

\section{The negative $\mathrm{e}^{52}$ aspect of Eriugena's theophanic asceticism}

Eriugena's asceticism has a negative aspect, which is focused on the struggle against vices, as well as a positive one, which is concentrated on the acqui-

\footnotetext{
${ }^{47}$ After the Fall, man has progressively opacified the theophanic nature of creation, by projecting his fallen and selfish desires toward the material world, thus making the world darker and more devoid of theophanic light: "The light of the cognition of God retreated from the world when man abandoned God", "Lux diuinae cognitionis de mundo recessit, dum homo deum deseruit” (Hom 11 289C, CCCM 166, 21. My translation.

${ }^{48}$ From $P P I V 827 \mathrm{D}-828 \mathrm{D}$, in the context of an extended discussion concerning the allegory of the Tree of Knowledge, Gen. 2.16-17*).

49 "seipsum in foetidissimam cupiditatis paludem immergens et ingurgitans", "nullum philargiae uenenum intentionem purae ipsius mentis inficit", PP IV 828C, SLH 13, 204-5. 50 "quasi incarnatum", Comm I, 29 307B, CCCM 166, 65.

51 "Quotiens prioris uitae modis et inferioris moritur [...], totiens [...] in sublimiores [...] theophanias fide atque intelligentia prouehetur”, Comm I, 32 312B, CCCM 166, 73. My translation.

${ }^{52}$ We use the term "negative" not in a passive sense ("negated", "rejected", "undesirable"), but in an active sense, meaning "negating", "rejecting", "renouncing". The "negative-positive" binomial with reference to Christian spirituality is accurately presented in: Dumitru Stăniloae, Orthodox Spirituality: A Practical Guide for the Faithful and a Definitive Manual for the Scholar, trans. Archimandrite Jerome and Otilia Kloos (South Canaan, Pennsylvania: St. Tikhon's Seminary Press, 2002), see especially the chapter: "The Goal of Orthodox Spirituality".
} 
sition of virtues. Both aspects are equally important given that one implies the other: "It is necessary that those who are meek in evil [...] not to be meek in good - that is, in the serious and diligent guarding of virtues -, [...] and never cease to fight against all the vices with an ever-vigilant soul" ${ }^{\prime \prime}$. This "ever-vigilant" opposition ${ }^{54}$ against sin receives significant consideration in John Scottus who interprets it from at least three perspectives: as repentance, as purgation, and as mortification.

\section{Repentance}

The negative aspect of Eriugena's asceticism is traditionally referred to as "repentance" (poenitentia), which consists in the grief (tristitia) over committed errors in view of their correction ${ }^{55}$. Repentance is always accompanied by a humble consciousness of our spiritual weakness and is regularly expressed as a sincere prayer for divine mercy:

Savior of the world, you who cleanse the foulness of the ages

and wash away all crime in the power of the Cross,

Almighty one, have pity on me in my grief;

for I am the cause of my own sorrow.

Grant me release from grief, grant life, grant wisdom;

I implore you, grant me the eternal kingdom of heaven ${ }^{56}$.

John Scottus illustrates repentance very pictorially: sometimes as spiritual compunction ${ }^{57}$, other times as an inner purgative flame ${ }^{58}$ which burns down every sin and above all pride ${ }^{59}$. The Irishman points out that, although repentance is a long-life process, it should begin as soon as possible, given that after death all repentance is "late and unavailing" ${ }^{\text {, }}$, as in the parable of the ten virgins (Matthew 25:1-13), which is extensively commented upon in $P P$ $V 1011 \mathrm{~A}-1018 \mathrm{D}^{61}$.

\footnotetext{
53 "Necesse est enim eos qui mites sunt in malo [...] immites fieri in bono, in bonarum uidelicet uirtutum seuera diligentique custodia [...], aduersus omnia uitia pugnare non desinentes, uigilique semper animo", Exp II, 4, 161C, CCCM 31, 41; cf. PP III 632A.

54 "tertia est quae opponitur malitiae, ut humilitas superbiae, castitas libidini. [...]; in quantum enim malitia uitiorum species multiplicat, in tantum bonitas uirtutum oppugnacula opponit”, PP III 632A, SLH 11, 56.

55 "correctricem in praesenti malorum poenitentiam", PP V916B, CCCM 165, 80.

${ }^{56}$ Carm. App. 2, vv. 17-22: "Saluator mundi, qui saecula sordida mundas, / Cum uirtute cruces criminal cuncta lauans, / Omnipotens, miserere mei, miserere dolentis: / Sum mihi namque mei causa doloris ego. / Da dolor absistat, da uitam daque sophiam: Des mihi perpetui, te rogo, regna poli”, SHL 12, 122-23.

57 "poenitentia compuncti", PP V 1018A, CCCM 165, 221.

58 “inflammatione poenitentiae exurit”, PP V 1003A, CCCM 165, 199.

59 "poenitendo, superbiamque suam deponendo", PP II 540B, SLH 9, 36.

60 "tardaque poenitentia et infructuosa", PP V 936A, CCCM 165, 106.

${ }^{61}$ Eriugena's exegesis to the parable of ten virgins is thoroughly analyzed in: Paul A. Dietrich, Donald F. Duclow, "Virgins in Paradise: Deification and Exegesis in «Periphyseon V»," in Jean
} 


\section{Purgation}

Yet a more important term in Eriugenian asceticism is "purgation" (purgatio), which John Scottus puts in close connection with St. Dionysius's concept of

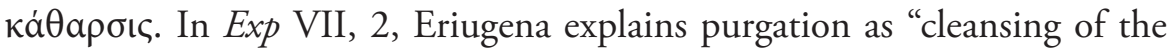
impure stains of sins and of the iniquities of our whole uncleanness"62. By "impure stains" the author refers to the phantasies of the corrupted mind which invaded the soul after its departure from the love of God and adhesion to the selfish love of creation ${ }^{63}$. Since the Fall, the human soul has progressively infested its perception of material things with the perverse desires of its irrational will and, consequently, attached to its memory all sort of vain images, thus nourishing more and more a false sense of self-satisfaction ${ }^{64}$. Therefore, the purpose of purgation is to eradicate all the phantasies from the memory and all the irrational motions from the human will, in order to let man again contemplate creation "with a simple eye" ${ }^{65}$, unmixed with any sinful desire.

Eriugena emphasizes the high difficulty of the purgative process, which is caused by the versatility of its object, which could easily take on the appearance of virtue and deceive the untrained mind: "false virtue [...] paints vices with the colours of virtues; [...] but the true and simple virtues it conceals $[. .$.$] so that it [the mind] may not be able to recognise their pure$ face" ${ }^{\prime 66}$. For this reason, Eriugena asserts that, at least for the first ascetical steps, man needs to stop focusing on the outer world and even to disdain his senses and his body:

he who lives perfectly not only altogether despises his body and the life force which administers it and all the corporeal senses together with the objects which they perceive, and all the irrational motions which he perceives in himself, together with the memory

Scot Écrivain. Actes du IVe colloque international de la SPES, ed. Guy-H. Allard (MontréalParis: Bellarmin-Vrin, 1986), 46-49.

62 "ab immundis maculis delictorum et inquinationibus totius nostre immunditie [...] purgationem”, Exp VII, 2, CCCM 31, 100.

63 "materialibus phantasiis, hoc est, falsis materialium rerum uanisque imaginationibus, quibus $[. .$.$] in rerum temporalium cupidinem opprimitur, diuersorum errorum anfractibus se-$ ducitur, et quod omnium perniciosissimum est, ab amore et cognitione ueritatis elongatur", Exp VII, 2, CCCM 31, 100-1.

64 "maxime carnalis anima, carnaliter plane uiuens", Exp VII, 2, CCCM 31, 100-101.

65 "simplicique mentis oculo", PP IV 835A, SLH 13, 218.

66 "falsa uirtus, [...] uitia uirtutum coloribus tingit, quae malitiam bonitati simulatiorie conformat $[. .$.$] ipsas uero simplices uerasque uirtutes dissimulate, [...] ne illarum sinceram faci-$ em possit agnoscere", PP IV 850A, SLH 13, 250-51. 
of all transient things, but also, in so far as he is able, does away with them and destroys them ${ }^{67}$.

Here it can be observed that, despite his intricate theory of the illusory nature of sin, Eriugena does not ignore the necessity of a concrete and fierce struggle against vices, which should be carried on not only spiritually, but also physically ${ }^{68}$.

Nevertheless, the struggle against the outer man and the bodily senses is not a rejection of the human body itself. Rather, Eriugena calls for a separation from the corrupt elements that emerged in it from sin, in order that man might be able, through his purified senses, to contemplate anew the theophanic essence of creation, as John Scottus exhorts in his Homily: "Perceive through the bodily sense the forms and beauties of sensible things, and comprehend the Word of God in them!" 69 .

Similarly, contempt for transient things should not be interpreted as a Manichean rejection of creation. On the contrary, contempt for the world is a specific aspect of purgation, aiming precisely at a fair valuation of creation, which, for Eriugena, has a sacramental character, namely to reveal God to the pure intellects. In fact, man only temporarily rejects the world, in order to see again the world in God.

\section{Mortification}

The spiritual struggle against sin is occasionally named "mortification"70, according to the Pauline verse: "Mortify your members of your wickedness" (Col. 3.5). Eriugena interprets "the members of wickedness" as a concrete result of the primordial disobedience, which brought about a "carnalization" of man's initially spiritual body:

he means us to mortify the members of our wickedness which are ours not because God created them, but as a result of our disobedience [...]; we have built up, as it were, a body of universal sin: it is this that we must mortify lest we be any longer defiled by it. ${ }^{71}$

\footnotetext{
67 " de die in diem [...] qui perfecte uiuit, omnino corpus suum, et uitam qua illud administratur, omnesque corporeos sensus cum his quae per eos percipit, omnesque irrationabiles motus quos in se sentit cum omnium rerum mutabilium memoria, non solum spernit, uerum etiam, quantum potest, et corrumpit et destruit", PP IV 753B, SLH 13, 26-27.

${ }^{68}$ Here and in some other places, Comm III, 2 316C, CCCM 166, 80, the charges of Docetism and of "conspicuous depreciations of the reality of the physical world", Colish, "John", 149, turn out to be invalid.

69 "Sensu corporeo formas ac pulchritudines rerum percipe sensibilium, et in eis intelliges dei uerbum”, Hom 11 289C, CCCM 166, 21-22.

${ }^{70}$ PP IV 747B, SLH 13, 12; PP V 892A, CCCM 165, 46.

71 "Ac si aperte diceret: Membra malitiae (quae uestra sunt, quoniam ex uestra inobedientia, et non ex deo facta) ex quibus ueluti quoddam corpus uniuersalis nequitiae aedificatis [...] ne ab eis diutius polluatur, mortificate", PP IV 747B, SLH 13, 12-13.
} 
Eriugena's peculiar understanding of the origin of our carnal body, which comes from a radical allegorical exegesis of Genesis 1-3, still does not lead him to advance the idea of a complete abolition of body; despite being a result of our primordial irrational motion, God allows the creation of body by virtue of a subtle divine pedagogy ${ }^{72}$ which waits to be efficiently and fruitfully apprehended.

Nevertheless, mortification receives full significance in relation to the spiritual goal of imitation of Christ (imitatio Christi). The aim of a personal and mystical imitation of Jesus's life demands that the believer appropriate even the most critical events in the historical life of the Lord: His passion, crucifixion, and death. Only by imitating these acts of Jesus, which best revealed His divine humility, can the faithful take decisive steps in overcoming pride and its tragic consequences: "So the pride of the mind [...] gave human nature over to death; from which only the humility of Christ and the love of spiritual things in faithful souls win her back and set her free"73.

In Comm I, 32, the ascetical process of dying with Christ is named specifically "con-crucifixion" with $\mathrm{Ch}^{-1}$ ist $^{74}$ :

Every one who believes in Christ, by his own power and by the disposition and quality of his virtue, is crucified and crucifies Christ for himself, that is, he is con-crucified with Christ. Indeed, one is crucified to sin, until, calming down from all its works in his flesh and through his flesh, he ends up knocked down like death; and he mortifies it, I mean the sin, with the nails of the fear of the Lord, until he restrains all its impulses, so that it can no longer work anything in his flesh. ${ }^{75}$

Thus, the believer crucifies sin with the nails of the fear of God, by a gradual dying to self and the world. At the end of this mystical crucifixion, one is

\footnotetext{
72 “ad usum mortalis uitae nostrae et exemplum”, PP II 584A-B, SLH 9, 132).

73 "Superbia itaque animi [...] naturam humanam mortis damnationi tradiderunt. De qua sola Christi humilitas et spiritualium rerum in animabus fidelium delectatio, eandem reuocat liberatque naturam", PP IV 848A, SLH 13, 247-48. Cf. PP III 627C: "humilitatis regula ubique obseruata, ne nosmet esse aestimemus, quod nos non sumus. Scriptum est enim: Noli altum sapere, sed time", SLH 11, 46.

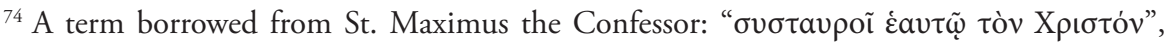
Maximos the Confessor, On Difficulties in the Church Fathers: The Ambigua, vol. 2, ed. and trans. Nicholas Constas (Cambridge, MA: Harvard University Press, 2014), 208; CCCM 166,72 .

75 "unusquisque credentium Christo, secundum propriam uirtutem, et subiectum sibi uirtutis habitum et qualitatem, et crucifigitur, et crucifigit sibimet ipsum Christum, Christo uidelicet concrucifixus. Unus quidem soli peccato crucifigitur, dum ab omnibus operationibus ipsius in carne et per carnem suam quietus, ueluti quadam morte obrutus efficitur; et illud, peccatum dico, clauis timoris Domini confixum mortificat, dum omnes ipsius impetus, ne quid in sua carne operari ualeant, refrenat", Comm I, 32 311B-C, CCCM 166, 72.
} 
buried, just like the Lord, in a spiritual tomb, waiting for the moment of his/ her personal resurrection. The spiritual resurrection of the faithful is equivalent to the emergence of virtues in his/her renewed nature, ${ }^{76}$ which makes obvious the fully positive aspect of Eriugena's asceticism.

\section{The positive aspect of Eriugena's theophanic asceticism}

As mentioned before, John Scottus's theophanic asceticism has not only a negative aspect consisting in uprooting vices, but also a positive aspect involving the implanting of virtues in place of vices. In fact, whenever the author discusses the process of purgation, the acquisition of moral virtues is almost always emphasized:

In the place of the elements of wickedness which we have destroyed, we should establish the elements of righteousness, that is to say, the virtues, so that in the same way as we, by our various vices, constructed an abominable temple fit only for the habitation of the devil upon the nature which God had created l, so we should now build anew from the stones of our virtues, which by the grace of God have been hewed out for $\mathrm{us}^{77}$.

From this text it can be concluded that mortification is not a purpose in itself, but only a means leading to the acquisition of virtues, which is the real purpose of asceticism and its necessary effect. From this perspective, mortification itself is only seemingly a negative process; in reality, it is a fully positive process meant to strengthen all man's spiritual powers by liberating human nature from the captivity of vices, with the purpose of becoming a "temple" for the habitation of the Lord ( $c f .1$ Cor. 3.16).

Eriugena labels the positive aspect of his theophanic asceticism with a Maximian concept: practica philosophia ${ }^{78}$, which he interprets as "the brilliant teacher of ethics"79. In John Scottus's view, the first stage of practical philosophy is obedience to divine commandments ${ }^{80}$. The observance of di-

\footnotetext{
76 "Mortificate uitia uestra, quae sunt supra soliditatem naturae, ut eradicatis eis uirtutum germina crescent", PP V 892A, CCCM 165, 46-47.

77 "et pro membris malitiae interemptis membra iustitiae (quae sunt uirtutes) constituite, ut, quemadmodum, super naturam ex Deo conditam, uestris diuersis criminibus ueluti templum quoddam abominabile diabolicaque habitatione condignum construxistis, ita etiam ex lapidibus uirtutum, diuina gratia dolatis [...] reaedificetis", PP IV 747B, SLH 13, 12-13. ${ }^{78}$ PP IV 857C, SLH 13, 268.

79 "Practica hic lucet morum praeclara magistra, / Custos uirtutum pervigil, idonea.", Carm 24, vv. 15-16, SLH 12, 114.

${ }^{80}$ Exp III, 1 174C: "Praecedit enim in ascensionibus uirtutum actio diuinorum mandatorum, per quam purgatur interior animi oculus [...] ut intimos summi boni radios in omnia diffusos ualeat sustinere”, CCCM 31, 56.
} 
vine laws leads the faithful, later on, to the abundant possession of virtues and to the unhindered performance of good deeds ${ }^{81}$, which represent different forms of the culminating virtue of love: "The law of grace teaches people not only to love one another, [...] but even to die, if required, for men, not only for the good, but also for the wicked." 82

Sometimes the Irishman describes the practica philosophia with other phrases, such as moralis philosophia or actiua philosophia, and explains: "The active philosophy deals with the unifications and distinctions of natural virtues", and "examines as much as possible the manner [of life] of the incarnate Word"83. Hence, not only in mortification, but also in the active philosophy, the supreme model and guide of the believer is Christ ${ }^{84}$. Nevertheless, in contrast to any other human model which is destined to be always external and distant from someone's self, Christ, the God-man, partakes mystically in the inner life of the believer and leads his attainment of virtues from within ${ }^{85}$.

\section{Virtues as theophanies}

In Eriugena's view, virtues are naturally regarded as God's manifestations in human beings: "Every theophany, that is, every virtue, [...] in this life in which it [the Divine Wisdom] is [...] beginning to take shape [in those] who are worthy to be formed..." ${ }^{86}$. Eriugena equates virtue with theophany from

${ }^{81}$ Comm III, 6 322AB: "Et quis est qui uenit ad lucem [...] ut manifestentur opera sua buna quia in deo sunt facta, nisi ipse qui credit in Christum et mandata eius custodit?", CCCM 166, 91. Cf. Comm III, 1 314C: "luce tamen perfectorum operum carent; [...] bonorum operum fiduciam non habentes", CCCM 166, 77.

${ }^{82}$ Comm I, 30 309B: "Lex gratiae est quae docet non solum homines se inuicem diligere [...] uerum etiam [...] pro hominibus non solum bonis uerum etiam et malis, si necesse est, mori", CCCM 166, 68-69.

83 "Actiua autem philosophia est quae circa naturalium uirtutum adunationes et discretiones uersatur. [...] rationes inhumanati Verbi, quantum ualet, considerat", Comm I, 32 312B, CCCM 166, 73. My translation.

${ }^{84}$ Hom 3 285B: "actio uirtutum, dei filium mirabili et ineffabili modo carne circumscriptum per uirtutem fidei et actionis conspicatur", CCCM 166, 8; Hom 23 296B: "In ipso, dico, quoniam maximum et principale exemplum gratiae", CCCM 166, 41; cf. Comm I 30 309B: "Quam legem Christus in se ipso adimpleuit, quando non solum pro omnibus hominibus, uerum etiam pro omnibus impiis passus est”, CCCM 166, 69.

85 "Descendit enim uerbum in hominem ut, per ipsum, ascenderet homo in deum", Comm I, 21 298A, CCCM 166, 48; "ex condescensione diuini Verbi [...] ad humanam naturam a se conditam atque purgatam, et exaltatione sursum uersus humanae naturae ad praedictum Verbum per diuinum amorem [...]. Ex ipsa igitur sapientiae dei condescensione ad humanam naturam per gratiam, et exaltatione eiusdem naturae ad ipsam sapientiam per dilectionem”, PP I 449AB, SLH 7, 52-53.

${ }^{86}$ PP I 449C: "omnis theophania, id est omnis uirtus, [...] in hac uita [in] qua adhuc incipit [in his] qui digni sunt formari...”, SLH 7, 54-55. 
an objective perspective: in the eyes of others, every virtue is a means by which Christ irradiates His divine goodness among them through the good deeds carried out by virtuous men toward their fellowmen. In his poems, Eriugena extols "the most righteous care for Christ's many paupers" 87 and praises the acts of charity of virtuous men for their theophanic capacity to raise people up to glorify $\mathrm{God}^{88}$.

But what is more relevant for John Scottus's spirituality is that virtues are theophanies from a subjective point of view too: every virtue and every good deed reveal God first and foremost in the soul itself of the virtuous $\operatorname{man}^{89}$. Drawing inspiration from the dogma of hypostatic union -i.e. of the intimate communication between divine and human nature in the incarnate Word -, Eriugena states that, after the Incarnation, Christ's divine power sustains all our spiritual efforts, by way of our intimate union with Him, which is made effective through our faith in Him: "There is no other way the Lord enters into the hearts of men than through faith, which is the Lord's way" ${ }^{\prime 0}$. Faith opens a way to the Lord Who enters into the heart of each believer with the purpose of a new incarnation under the form of virtues: "Daily then is Christ conceived, born, and nourished in the womb of Faith as in the womb of a most chaste mother"

John Scottus points out that each virtue is a "conformation" (conformatio) of Christ in us, more exactly an engraving of Christ's sanctity and wisdom in us and a sharing of His divine "form" in our human nature: "From the one and the same Form which all things desire [I mean the Word of God] each shall receive a form according to the degree of his own sanctity and wisdom"92. In Eriugena's view, virtues are theophanies precisely because

${ }^{87}$ Carm 4, vv. 15-16: "Pauperibus multis Christi iustissima cura”, SLH 12, 72. My translation.

${ }^{88}$ Carm 4, vv. 41-42: "Deuotis animis semper te laudet uterque, / [...] actibus atque bonis", SLH 12, 74.

${ }^{89} \operatorname{Exp}$ VI, 4 343C: "contemplationem, quae totius bonae operationis fructus est", CCCM $166,129$.

90 "Non enim per aliam viam Dominus corda hominum ingreditur, nisi per fidem, quae via est Domini", Comm I, 28 305A, CCCM 166, 61; cf. PP I 516C: "Dicitur etiam in animabus fidelium fieri, dum aut per fidem et uirtutem in eis concipitur", in Sheldon-Williams's translation: "He is also said to be made in the souls of the faithful when $\mathrm{He}$ is either conceived in them by faith and virtue", SLH 7, 204-205.

${ }_{91}$ "Quotidie igitur Christus in utero fidei ueluti castissimae matris uisceribus et concipitur et nascitur et nutritur", PP II 611D, SLH 9, 194-95.

92 "Vnusquisque [...] secundum suae sanctitatis atque sapientiae celsitudinem ab una eademque forma quam omnia appetunt, [dei uerbum dico,] formabitur", PP I 448C, SLH 7 , $50-53$. 
Christ Himself is "the cause and substance of all virtues" 93 Who molds virtuous men into infinite shapes: "In the purest minds the Infinite acquires infinite forms" ${ }^{\prime 4}$. Christ intensifies man's spiritual progress in virtues ${ }^{95}$ as $\mathrm{He}$ reveals Himself more and more brightly to his inner eye: "the virtues of the purest souls and intellects are theophanies and through them God manifests Himself to those who seek and love Him" ${ }^{\prime 6}$.

\section{Grace}

John Scottus's theophanic asceticism is never regarded as a unilateral practice of moral discipline, independent of cooperation with Christ's grace, i.e. with His merciful, gratuitous, and sanctifying assistance ${ }^{97}$. In fact, Christ's assistance in man's ascetical efforts is so evident for Eriugena, that he affirms, without any hesitation, that, during the ascetical struggle, it is Christ Himself Who "dies day by day in His believers and is crucified by them" 98 .

Moreover, the Irishman suggests that divine grace is required not only in a certain moment during human asceticism, but from the very beginning of man's spiritual ascension; in fact, it is God's grace that provokes the first impulse toward the good in the soul of the believer without any preceding merits 99 : "divine grace causes our purification", and from then on "performs

93 "causa omnium uirtutum et substantia”, PP I 449C, SLH7, 54. In a discussion concerning Christ as the "All-Tree" in paradise, Eriugena emphasizes that "It alone is the substantial Good. The other things which are called good are good not through themselves but through participation in Him Who in Himself truly is the Good Which is, and all good and goodness, and the fount and origin [...] of all good and goodness"; "Ipsum enim solummodo est substantiale bonum, caetera enim quae dicuntur esse bona, non per se, sed participatione ipsius bona sunt, qui per se uere existens bonum est, et omne bonum, et bonitas, et totius boni et bonitatis fons et origo...", PP IV 823C, SLH 13, 192-93.

${ }^{94}$ Comm I, 32 312B: "Infinitus enim infinite etiam in purgatissimis mentibus formatur", CCCM 166, 73. My translation.

${ }^{95}$ In fact, while acquiring a certain virtue, the faithful gains all virtues, because all virtues attract one another and form a unity in the harmony of their divine Cause, in contrast with the constantly discordant, divisive and destructive tendencies of vices, $\operatorname{Exp}$ XV, $4264 \mathrm{~B}$, CCCM 31, 202.

${ }^{96} \mathrm{Comm} \mathrm{I,} 27$ 302B: "uirtutes purgatissimum animarum et intellectuum theophaniae sunt, et in eis quaerentibus et diligentibus se deus <seipsum> manifestat", CCCM 166, 55.

${ }^{97}$ De diuina praedestinatione IV, 1 370C (hereafter Praed): "gratiae auxilium [...] profecto plenitudo iustitiae hominis et inchoatur et perficitur"; Iohannis Scotti, De diuina praedestinatione liber, ed. Goulven Madec, CCCM 50 (Turnholt: Brepols, 1978), 27; Praed VIII, 9 389C: "praeparante ipsum ipsique cooperante gratuito diuinae gratiae multiplicique dono", CCCM 50, 54-55.

${ }^{98}$ Comm I, 32 312A: "Itaque in suis fidelibus Christus quotidie moritur, et ab eis crucifigitur,", CCCM 166, 73. My translation.

${ }^{99}$ Hom 23 296B: "nullis meritis praecedentibus", CCCM 166, 41. 
it together with us"100 and sustains it steadily to the highest peaks of perfection: "he [the believer] ascends from virtue to virtue by the movement and co-operation and leadership and perfecting power of God's grace"101. By highlighting both the necessity and the precedence of grace in man's ascetical efforts, Eriugena takes a stand against the Pelagian conception which used to consider divine grace to be of no profit to man, as well as against the SemiPelagian conception which used to claim that the beginning of faith depends solely on our free will, with grace supervening only later on. Obviously, John Scottus also condemns the opposing belief that grace alone is sufficient to man's spiritual ascension without the exercise of free will and concludes that

the king's highway must then be trodden with no turning aside to right or to left, which means that free choice must not be defended in such a way that good works are attributed to it without the grace of God; nor must grace be so defended that, as it were from the safety afforded by it, evil deeds may be habitually performed. ${ }^{102}$

\section{Sacraments}

In Eriugena's view, Christ's supreme sacrifice for humanity brought about an "exceedingly profound, vast and infinite effusion of grace upon our human nature" 103 . This limitlessly abundant grace is accessible to man in a general manner (generaliter) by participating in all natural goods of the very fact of existence ${ }^{104}$, as well as in a special manner (specialiter), by a willing and intensive cooperation with grace, manifested in: faith ${ }^{105}$, prayer $^{106}$, Bible study ${ }^{107}$, partaking of sacraments.

\footnotetext{
100 "diuina gratia nostram purgationem operante et cooperante", Exp VII, 2 179D, CCCM 31, 100. My translation.

101 "se ipsum uero, in quantum caelestis essentiae particeps est, [...] uirtute in uirtutem [...] diuina gratia mouente, cooperante, ducente, perficiente renouat", PP IV 753B, SLH 13, 26-27.

${ }^{102}$ Mary Brenan's translation in: John Scottus Eriugena, Treatise on Divine Predestination (Notre Dame, Indiana: University of Notre Dame Press, 1998), 27, of Praed IV, 3 371CD: "Via igitur regia gradiendum nec ad dexteram nec ad sinistram diuertendum, hoc est ne sic defendatur liberum arbitrium ut ei bona opera sine dei gratia tribuantur, nec sic defendatur gratia ut quasi de illa securi mala opera diligantur”, CCCM 50, 29.

103 "profundissima copiosissimaque atque infinita effusione gratiae, quae in pretium sanguinis Christi humanae naturae diffusa est”, PP V 1002B, CCCM 165, 198.

104 "Nullum namque substantiale vel essentiale bonum per se est, praeter ipsam solam, cuius participatio dat omnibus bona esse”, PP V903C, CCCM 165, 62.

105 "generaliter quidem omnibus resurrectionis et uitae gratiam praestans, specialiter uero in se credentibus", PP V985D, CCCM 165, 175; "uniuscuiusque cordis deuotio diuina gratia adiuta fuerit...”, PP V 1001D, CCCM 165, 198.

106 See above notes 22-23.

107 "studio nostram intelligentiam exercendi, sudorisque et inventionis praemii reddendi...", PP V 1010B, CCCM 165, 210; "Orans, legitans libros, manibusque laborans”, Carm 4, v. 19, SLH 12, 72.
} 
John Scottus mentions three sacraments: baptism, communion and chrismation ${ }^{108}$ and deals particularly with the first two. For him, the sacrament of baptism and that of communion are two tangible ${ }^{109}$ vehicles through which Christ's grace establishes and sustains the Church: "when Christ is dead His side is pierced that the sacraments may flow forth upon which the Church is built. For the blood stands for the consecration of the cup, the water for the consecration of baptism"110.

The sacrament of baptism is the first fruit of the cooperation between human will and God's grace and it initiates man's new life in the Spirit: "through the grace of baptism the believers in Christ begin to be born in God"111. Through baptism, God's holiness is received personally and existentially: "the power of the sacrament sanctifies the bodies of the faithful in this life, as they become a temple of the Holy Spirit" 112 .

After accessing the rivers of divine grace through baptism ${ }^{113}$, the believer enlarges more and more his reception of God's holiness by continual partaking in "the most holy supper"114. In the mystery of the Eucharist the participant tastes the "flesh of Christ", "the Manna befitting the highest virtues"115, and drinks "the blood of the Lamb" which "flowed for the salvation of all mankind" 116 .

At the beginning, the Eucharist bestows upon the believer the grace of purification: "we, who after [...] the Resurrection believe in Him and

\footnotetext{
${ }^{108}$ Comm I, 30 308C, CCCM 166, 67.

109 "Since man is comprised of a visible body and an invisible soul, it was necessary that a sacrament be visible [...], just as the invisible doctrine of the faith for the sanctification of the invisible soul is necessary", "quoniam homo ex uisibili corpore et inuisibili anima constituitur, necessarium erat sacramentum uisibile [...], sicut necessaria est inuisibilis fidei doctrina ad sanctificationem inuisibilis animae", Comm III, 2, CCCM 166, 80.

110 "mortuo Christo pertutitur latus, ut profluant sacramenta quibus formatur ecclesia. Sanguis enim est in consecrationem calicis, aqua uero in consecrationem baptismatis", $P P$ IV 836D, SLH 13, 222-23.

111 "per gratiam [...] baptismatis [...] incipiunt credentes in Christum ex Deo nasci", Comm I, 21 297C, CCCM 166, 48.

112 "in praesenti uita sanctificat fidelium corpora uirtus sacramenti, cum templum dei efficiantur", Comm III, 2 316D, CCCM 166, 80-81. Cf. Comm III, 1 314B: "nondum tamen baptizati, neque sacramento corporis et sanguinis Domini imbuti”, CCCM 166, 77.

113 "per fluenta divinae gratiae, quae primitus per sacramenta baptismatis distribuuntur", Comm I, 21 297C, CCCM 166, 48.

${ }^{114}$ Carm 10, v. 20: "Officio uatum sanctissima cena paratur", SLH 12, 96.

${ }^{115}$ Carm 9, v. 23: "CAPE [...] Christi”, SLH 12, 90; Carm 25, v. 58: “manna [...] summis uirtutibus aptum”, SLH 12, 118.

${ }^{116}$ App. 11, v. 1: "Suscipit, agne, tuum populus, uenedande, cruorem", SLH 12, 128; "cuius sanguis communiter pro salute totius humanitatis fusus est", PPV1020B, CCCM 165, 224. My translation.
} 
understand His mysteries, as much as we are granted, immolate Him spiritually and eat Him intellectually" 117 . Christ's "immolation" in us is nothing but our con-crucifixion with Him in respect to our previous sinful life. The correlation in this place between His immolation in us and our eating of His eucharistic flesh indicates the enormous purgative power that the sacrament of communion has on our inner life. This power originates from Christ's coming into the hearts of the faithful in order to die with each of them in their spiritual mortification and to resurrect with each of them to a new life ${ }^{118}$ full of virtue, knowledge and contemplation:

For the Lamb offers to those who acquire Him three things: milk, wool and even the eating of His flesh. Our Lord furnishes to His believers the garments of virtues; nourishes them with milk, namely with the simple doctrine of truth; and leads them to the perfect nurture of His divine contemplation. ${ }^{119}$

It is not by chance that the spiritual gifts imparted by the Lamb to the faithful are presented in a gradation culminating in the contemplation of Christ: this reveals that the Eucharist too has a profound theophanic character. Undoubtedly, in John Scottus's theophanic framework, according to which the universe in all its parts has a sacramental quality and "there is nothing among visible and corporeal things which does not signify something incorporeal and intelligible" 120 sacraments are regarded as theophanies par excellence. From this perspective, the direct contact with the visible and sanctified matter of the sacrament is meant to lead the faithful to the greater reality it signifies, namely to the intimate perception of Christ's spiritual presence which far exceeds the boundaries of the visible sacrament:

this visible eucharist, which the priests of the Church prepare at the altar from the tangible matter of bread and wine and which they receive bodily after it has been prepared and sanctified, is a typical similitude of the spiritual participation in Jesus whom we taste by faith through understanding alone $[. .$.$] whom we receive$

\footnotetext{
117 "nos, qui post [...] resurrectionem in eum credimus eiusque mysteria, quantum nobis conceditur, intelligimus, et spiritualiter eum immolamus et intellectualiter [...] comedimus", Comm I, 31 311B, CCCM 166, 71-72.

${ }^{118}$ Comm I, 32 312D: "Sic agnus dei in cordibus fidelium mactatur et mactando uiuificatur", CCCM 166, 70.

${ }^{119}$ Comm I, 31 310B: "Tria enim agnus possidentibus se ministrat: lac, lanam, esum quoque suae carnis. Dominus noster credentibus se indumenta praestat uirtutum, lacte (hoc est simplici doctrina ueritatis) eos nutrit, et ad perfectam escam diuinae suae contemplationis perducit”, CCCM 166, 70. My translation.

120 "Nihil enim uisibilium rerum corporaliumque est [...] quod non incorporale quid et intelligibile significet”, PP V 866A, CCCM 165, 10. My translation.
} 
into the inner entrails of our nature for our salvation and spiritual growth and ineffable deification. ${ }^{121}$

It is remarkable that, in a time when the official discourse of the Church emphasized the doctrine of transubstantiation (the substantial change from bread and wine to flesh and blood of Christ in the offering of the Eucharist $)^{122}$, Eriugena deliberately regarded the presence of Christ in the Eucharist in terms of theophany. John Scottus avoided the common transubstantialist view precisely because transubstantiation would mean in his perspective to misunderstand the theophanic role of the sacrament, which is to hint beyond itself to a greater spiritual reality ${ }^{123}$.

As far as the question of the presence of Christ in the Eucharist is concerned, Eriugena's statements such as: "the flesh of Christ is the most real life" and "[He is] the Bread, the eternal Bread which sustains all things" 124 , make us understand that the Irishman would not dispute at all Christ's presence in the mystery of communion, if this presence was understood in accordance with the very nature of the sacrament, which is "mystical", namely more than "real" or "sensible". Eriugena's intention is to prevent the risk of a harmful reductionism that the common transubstantialist view could easily support ${ }^{125}$. Therefore, he always pleads for a rather theophanic approach to the E ucharist ${ }^{126}$, never regarded as a goal in itself, but as a means to experi-

${ }^{121}$ Exp I, 3 140B: "uisibilem hanc eucharistiam, quam quotidie sacerdotes Ecclesie in altari conficiunt ex sensibili materia panis et vini, quamque confectam et sanctificatam corporaliter accipiunt, typicam esse similitudinem spiritualis participationis Iesu, quem fideliter solo intellectu gustamus [...], inque nostre nature interiora uiscera sumimus ad nostram salutem et spirituale incrementum et ineffabilem deificationem", CCCM 31, 16. My translation.

122 See: Celia Chazelle, The Crucified God in the Carolingian Era: Theology and Art of Christ's Passion (Cambridge: Cambridge University Press, 2001), 209-38.

${ }^{123}$ For more details about the theophanic nature of the sacraments in Eriugena, see: George S.M. Walker, "Eriugena's Conception of the Sacraments," in Studies in Church History, vol. 3, ed. Geoffrey J. Cuming (Leiden: Brill, 1966), 150-58.

${ }^{124}$ Carm 9, v. 23: "CAPE [...] Christi substat uerissima uita” (SLH 12, 90); Carm 25, v. 56-57: "qui sustinet omnia, panis, / Panis perpetuus", SLH 12, 118. My translation.

${ }^{125}$ Eriugena critiques the radical substantialist conception of some of his contemporaries (possibly Paschasius Radbertus of Corbie and his supporters) who saw in the Eucharist nothing "beyond itself", probably meaning beyond its material contents: "Quid ergo ad hanc magni theologi Dionysii preclarissimam tubam respondent, qui uisibilem eucharistiam nil aliud significare preter seipsam volunt asserere...?”, Exp I, 3, CCCM 31, 17.

${ }^{126}$ In this interpretation Eriugena is indebted to Dionysius, whose sacramental symbolism is far from the later transubstantialist perspective: "he [Dionysius] does not advance a special procession of the divinity into the ritual objects themselves, e. g., transubstantiation. Even the most sacred physical objects such as the myron, the bread, and the cup, are not direct emanations of the divine in any sense of a "substantial» presence", Paul Rorem, Biblical and liturgical symbols within the pseudo-Dionysian synthesis (Toronto: Pontifical Institute of Mediaeval Studies, 1984), 66. 
ence the greater reality of the "ineffable deification", which itself is nothing but an intimate and unceasing "theophany" 127.

\section{Conclusion}

Eriugena can definitely be considered a mystical author. In his mystical theory, the Irishman employed a central concept that carries a great density of meanings, i.e. theophany, which he borrowed from Ps.-Dionysius the Areopagite and whose mystical potential Eriugena exploited even better than his Greek source. One can notice in John Scottus's works that his ultimate goal was to lead the readers toward the highest theophanies, understood as forms of deification or mystical union with God. With this purpose, he displays here and there in his auvre the stages of an ascetical preparation, without which the mystical encounter with God in theophany is rather impossible. This paper sets forth some aspects of John Scottus's asceticism, by organizing them into two categories: (1) negative aspects of asceticism, such as repentance, purgation, mortification, and (2) positive aspects of asceticism, such as virtues, grace and sacraments. In shaping his theophanic asceticism, Eriugena adapted the doctrine of the hypostatic union to man's spiritual ascension in such a way that the cooperation between human will and divine grace appears entirely necessary. The connecting thread of John Scottus's complex asceticism is the idea that Christ, the God-man, partakes mystically in the inner life of the believer and leads from within his/her ascent toward higher and higher theophanies.

\footnotetext{
127 “[Condescensionem hic dico non eam quae iam facta est per incarnationem sed eam quae fit per theosin, id est per deificationem, creaturae]. Ex ipsa igitur sapientiae dei condescensione ad humanam naturam per gratiam et exaltatione eiusdem naturae ad ipsam sapientiam per dilectionem fit theophania”, PP I 449B, SLH 7, 52.
} 